\title{
Microbiological Analysis in Three Diverse Natural Geothermal Bathing Pools in Iceland
}

\section{Berglind Osk Th. Thorolfsdottir ${ }^{1,2, *}$ and Viggo Thor Marteinsson ${ }^{1, *}$}

1 Matis, Department of Food Safety, Environment and Genetics, Vínlandsleið 12, Reykjavík 113, Iceland

2 School of Engineering and Natural Sciences, University of Iceland, Sæmundargata 2, Reykjavík 101, Iceland

* Authors to whom correspondence should be addressed; E-Mails: bth650@ gmail.com (B.O.T.T.); viggo@matis.is (V.T.M.); Tel.: +354-422-5000; Fax: +354-422-5001.

Received: 19 January 2013; in revised form: 22 February 2013 / Accepted: 8 March 2013 /

Published: 14 March 2013

\begin{abstract}
Natural thermal bathing pools contain geothermal water that is very popular to bathe in but the water is not sterilized, irradiated or treated in any way. Increasing tourism in Iceland will lead to increasing numbers of bath guests, which can in turn affect the microbial flora in the pools and therefore user safety. Today, there is no legislation that applies to natural geothermal pools in Iceland, as the water is not used for consumption and the pools are not defined as public swimming pools. In this study, we conducted a microbiological analysis on three popular but different natural pools in Iceland, located at Lýsuhóll, Hveravellir and Landmannalaugar. Total bacterial counts were performed by flow cytometry, and with plate count at $22{ }^{\circ} \mathrm{C}, 37^{\circ} \mathrm{C}$ and $50{ }^{\circ} \mathrm{C}$. The presence of viable coliforms, Enterococcus spp. and pseudomonads were investigated by growth experiments on selective media. All samples were screened for noroviruses by real time PCR. The results indicate higher fecal contamination in the geothermal pools where the geothermal water flow was low and bathing guest count was high during the day. The number of cultivated Pseudomonas spp. was high $(13,000-40,000 \mathrm{cfu} / 100 \mathrm{~mL})$ in the natural pools, and several strains were isolated and classified as opportunistic pathogens. Norovirus was not detected in the three pools. DNA was extracted from one-liter samples in each pool and analyzed by partial $16 \mathrm{~S}$ rRNA gene sequencing. Microbial diversity analysis revealed different microbial communities between the pools and they were primarily composed of alpha-, beta- and gammaproteobacteria.
\end{abstract}


Keywords: natural geothermal pool; bacterial count; microbiological parameters; cultured and uncultured bacteria; 16S rRNA gene sequencing

\section{Introduction}

Geothermal heat is found in over 700 locations in Iceland [1]. Natural thermal bathing pools are important local resources that have been used by the people in Iceland for centuries. A natural thermal pool is defined as a pool with geothermal water that has not been sterilized, irradiated or treated in any way [2]. There is no legislation that applies to the natural pools in Iceland, so people bathe in them entirely at their own risk. Water for traditional or municipal swimming pools must always fulfill bacteriological water quality criteria and contain a certain chlorine concentration to keep it free from bacteria. However, when the quality of natural thermal pool water is assessed, it does not comply with the criteria for traditional swimming pools. Iceland has not implemented the new EU Bathing Water Directive of 2006.

A vast diversity of microorganisms can be found in pools and other waters used for recreation, originating from different sources, such as humans, animals or the environment. Diseases, some very serious, can be transmitted with bathwater if it is not disinfected before bathing. In many cases such infections have been associated with fecal contamination of the water. Fecal contamination can come from the pool guests' feces, the water supply itself or from animal feces (such as birds and small animals). Other body fluids (e.g., vomit, mucus, saliva) and flakes of skin are also potential sources of pathogenic bacteria. The best indicators for the assessment of the safety of swimming pool water are disputed. Some researchers emphasize that the microbiological quality of swimming pools is effectively measured by using bacteria that indicate fecal contamination, such as fecal coliforms and enterococci [3]. Others consider that the risk of infection is more associated with microorganisms derived from the skin, mouth, and upper respiratory tract of bathers [3,4]. Therefore, it might be good to detect bacteria from feces as well as other human body fluids.

It should be kept in mind that not all diseases stem from bacteria found in the bathwater itself. Infections can occur due to the natural bacterial flora of the body thriving in response to a reduced immune system following bathing and cooling, so-called "opportunistic pathogens" [5]. Human infection via bathing water can be achieved by direct contact (through cracks in the skin), from air through the respiratory system or directly from the water entering the gastrointestinal tract through the mouth. Studies have shown that while swimming (average $81 \mathrm{~min}$ ), children absorb an average of $0.63 \mathrm{~mL} / \mathrm{min}$ of pool water, adult men $0.50 \mathrm{~mL} / \mathrm{min}$, and adult women $0.34 \mathrm{~mL} / \mathrm{min}$ [6].

The public health and safety of natural thermal pools in Iceland has not been monitored on a regular basis. A bacterial analysis was conducted on 1-3 water samples from nine sites in 2002 and the results were presented in a report [2]. The samples were examined for total bacterial count in culture at $37{ }^{\circ} \mathrm{C}$, fecal coliforms, Pseudomonas aeruginosa and Staphylococcus aureus. Conductivity, turbidity and $\mathrm{pH}$ were also measured. Results of the analysis gave some indications of water quality and environmental factors of the sites. The results indicated that there were some differences between locations depending on the guest count and location. A high count of fecal coliforms was measured at one point and time in 
the Blue Lagoon (800 cfu (colony forming units)/100 mL), Landmannalaugar (550) and several samples from Hveravellir (570-1,300). Pseudomonas aeruginosa was also found to be at high count in the Blue Lagoon (200), Laugafell (300), Hveravellir (20,000) and Landmannalaugar (500). The results indicated that "to have a significant picture of the condition of natural pool in Iceland they should be monitored regularly, as their bacterial condition may vary due to man-made changes and changes in the natural environment" [2]. The Public Health Authorities have analyzed water samples from natural pools over the years, but since no regulation exists for these pools, the sampling and measurements have neither been regular nor many.

People are known to bathe in thermal pools in many places around the world, e.g., in France, Germany, Austria, Chechnya, Hungary, Japan, Taiwan, etc., but man-made recreational spas are far more common. Many EU countries have implemented the Bathing Water Directive of 2006, which means they monitor their beaches and inland waters that are used for bathing.

The objective of the study was to assess the microbiological status of Icelandic natural thermal bathing pools by evaluating their microbial diversity by partial 16S rRNA gene sequencing; by comparing total cell count performed by flow cytometry to total viable plate count analysis (at $22{ }^{\circ} \mathrm{C}$, $37^{\circ} \mathrm{C}$ and $50{ }^{\circ} \mathrm{C}$ ); and finally by testing for the presence of viable coliforms, intestinal enterococci, Pseudomonas aeruginosa using selective media and noroviruses by real time PCR to estimate the relation between fecal contamination, guest count and water flow of the pools.

Figure 1. Locations of the study areas in Iceland.

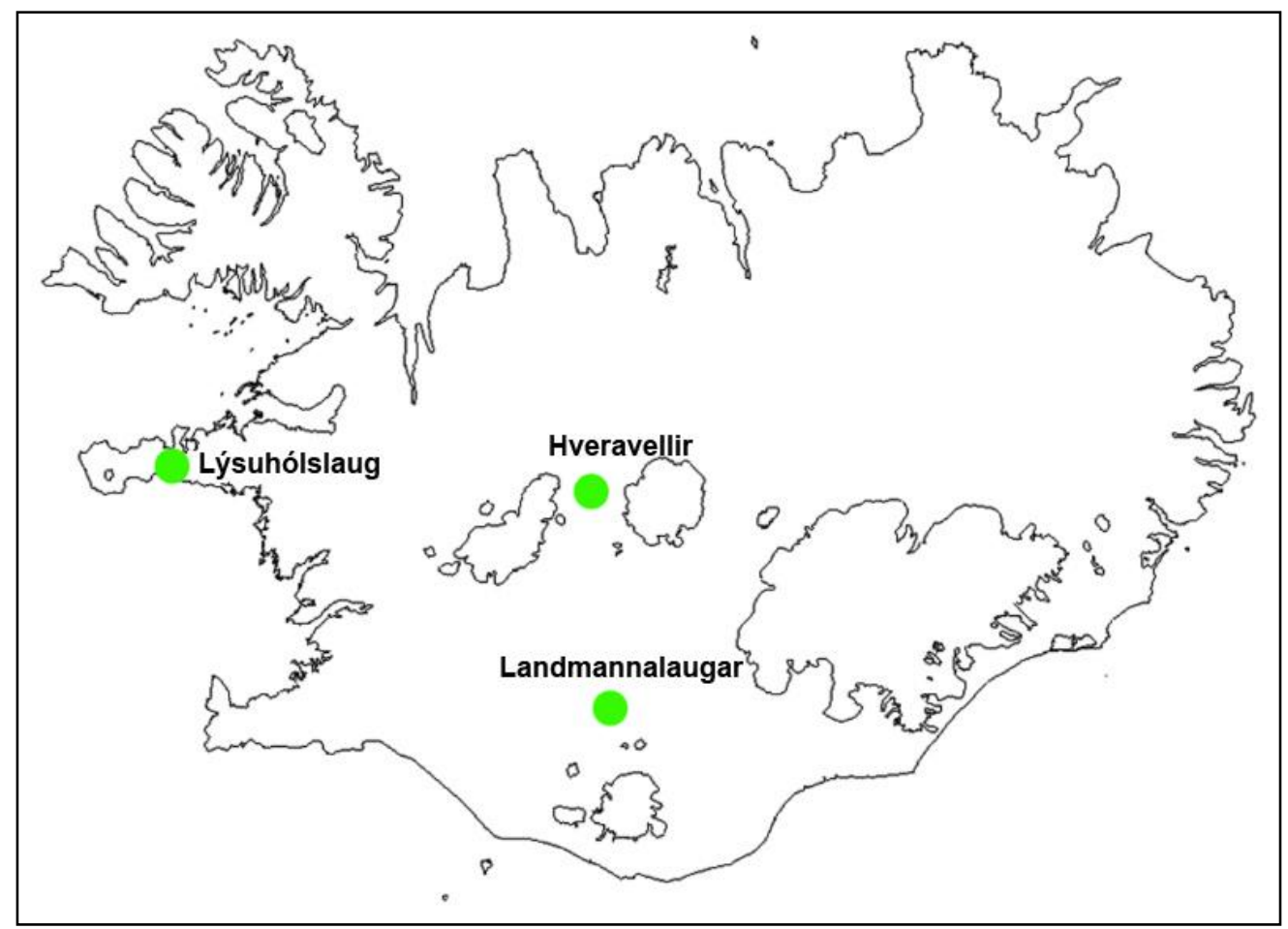




\section{Materials and Methods}

\subsection{Study Areas}

The study areas were three physically different natural pools (Figure 1): Hveravellir in the western part of the highlands (630 m above sea level), Landmannalaugar (500 m.a.s.1.) in the southern part of the highlands, and Lýsuhólslaug in the western part of Iceland (lowland). The natural pool at Hveravellir is made up of stones, located at a high temperature geothermal area where the water is piped a short way from a hot spring. The pool at Landmannalaugar was constructed by damming a big lake that flows from underneath the lava-rock in a low temperature area. Lýsuhólslaug is a completely man-made concrete pool, where the water is piped a fairly long way from a drilled well in the low temperature area. The pools are all operated during the summer and are attended by both foreign and domestic travelers. During the high tourism season, the number of guests is about 40,000 in Hveravellir, 100,000 in Landmannalaugar and 5,000 in Lýsuhólslaug.

\subsection{Sample Collection, Filtration, Cultivation and Confirmation}

Water samples were collected from Lýsuhólslaug on 17 July 2011 (Sunday), 14 August 2011 (Sunday) from Hveravellir, and 24 August 2011 (Wednesday) from Landmannalaugar. Sterilized 5 -liter plastic bottles were used and five samples were collected at $20 \mathrm{~cm}$ below surface over a 7-13 h period. Temperature, $\mathrm{pH}$ and guest count were also recorded. The samples were kept in a cooling box during the day of the sample collection and kept at $4{ }^{\circ} \mathrm{C}$ overnight before they were processed (12-24 h after sampling, due to the distant geographical position of the natural pools).

The water samples were quantitatively analyzed for the microbiological parameters of total bacterial count at $22{ }^{\circ} \mathrm{C}, 37{ }^{\circ} \mathrm{C}$ and $50{ }^{\circ} \mathrm{C}$, intestinal enterococci, E. coli and Pseudomonas aeruginosa. The media used in the procedure were prepared according to the instruction of the manufacturers. Samples of different size $(100,10,1$ and $0.1 \mathrm{~mL})$ were filtered through $0.22 \mu \mathrm{m}$ membrane filter and the filter placed on the appropriate agar medium; total bacterial count on R2A (Difco R2A agar REF 218263, incubated 2-5 days), E. coli on mFC agar (Difco, REF 267720) incubated at $44{ }^{\circ} \mathrm{C}$ for $24 \mathrm{~h}$, and confirmed in lactose broth (Oxoid, CM0137) after $24 \mathrm{~h}$ incubation at $44{ }^{\circ} \mathrm{C}$, intestinal enterococci on Slanetz \& Bartley agar (Oxoid, CM0377) incubated at $37{ }^{\circ} \mathrm{C}$ for $48 \mathrm{~h}$ and confirmed on Bile aesculin agar (Oxoid, CM0888) after $2 \mathrm{~h}$ incubation at $44{ }^{\circ} \mathrm{C}, P$. aeruginosa on CNA (Oxoid Pseudomonas agar base CM0559), incubated for $48 \mathrm{~h}$ at $37{ }^{\circ} \mathrm{C}$, and confirmed in acetamide broth (Merck, 1.01394) incubated for 24 at $37{ }^{\circ} \mathrm{C}$. 1-2 drops of Nessler's reagent was then added. One liter of each sample was filtrated for DNA extraction, $16 \mathrm{~S}$ rDNA amplification and analysis.

\subsection{Flow Cytometry}

Five $\mathrm{mL}$ of water from each sample were frozen in $120 \mu \mathrm{L}$ of $5 \%$ glutaraldehyde at $-80{ }^{\circ} \mathrm{C}$ for cell count. All samples were analyzed on a BD FACS ARIA ${ }^{\mathrm{TM}}$ II (BD Biosciences, CA, USA). Samples $(300 \mu \mathrm{L})$ were mixed with $3 \mu \mathrm{L}$ of $1 / 100$ diluted SYBR Green and incubated for 20 min at room temperature. Twenty-five $\mu \mathrm{L}$ of counting beads (CountBright ${ }^{\mathrm{TM}}$ absolute counting beads from Invitrogen, Life Technologies, Carlsbad, CA, USA) were then put in the mix before they were placed 
in the flow cytometer. Samples flowed through the cytometer for $30 \mathrm{~s}$ (elapsed time) and then events were recorded and counted for $1 \mathrm{~min}$. The BD FACSDiva ${ }^{\mathrm{TM}}$ Software (BD Biosciences, San Jose, CA, USA) was used for controlling the instrument and recording data.

\subsection{Real-Time PCR for Norovirus}

Real-time polymerase chain reaction for norovirus genotype 1 was performed for the last sample taken in each pool. Viral RNA was extracted from $140 \mathrm{~mL}$ of pre-filtered and treated sample using a QIAamp Viral RNA Mini Kit (Qiagen Inc., Germantown, MD, USA), according to the manufacturer's instructions. All real time PCR reactions were performed using Brilliant II QRT-PCR 1-Step Master Mix (Agilent Technologies, CA, USA) and MX3005p real time PCR machine (Agilent Tecnologies, Palo Alto, CA, USA). Norovirus GI real time RT-PCR detection was performed using $5 \mu$ of viral RNA template in $25 \mu \mathrm{l}$ reaction volume, $600 \mathrm{nM}$ of each primer (QNIF4 and NViLCR) and $200 \mathrm{nM}$ probe (TM9). After an initial RT step of $30 \mathrm{~min}$ at $50{ }^{\circ} \mathrm{C}$ the reaction mixture was incubated at $95{ }^{\circ} \mathrm{C}$ for 10 min followed by 40 cycles of $95{ }^{\circ} \mathrm{C}$ for $30 \mathrm{~s}, 50{ }^{\circ} \mathrm{C}$ for $30 \mathrm{~s}$ and $72{ }^{\circ} \mathrm{C}$ for $30 \mathrm{~s}$, finishing with a final extension step at $72{ }^{\circ} \mathrm{C}$ for $7 \mathrm{~min}$. Both undiluted and $10 \times$ diluted samples were PCR amplified along with a positive GI control (RNA isolated from a contaminated fecal sample).

\subsection{DNA Extraction}

For the extraction of total DNA from the pool water, 1 liter of the last collected sample (taken at the end of the day) was filtered through a sterile gridded $0.45 \mu \mathrm{m}$ pore size cellulose membrane filter (Millipore Corporation, Bedford, MA, USA) to capture microbial cells. Isolation of chromosomal DNA was carried out by the KingFisher ${ }^{\circledR}$ method (Thermo Scientific, Waltham, MA, USA).

\subsection{Bacterial 16S rRNA Gene Clone Libraries and Sequencing}

Extracted DNA was PCR-amplified in a DNA engine, Terad $^{\circledR} 2$ Peltier Thermal Cycler (Bio Rad, Hercules, CA, USA), using the primer pair 341F (5'-CCTACGGGNGGCWGCAG-3') [7] and 1046R (5'-CGACAGCCATGCANCACCT-3') [8]. A solution of $2 \mu \mathrm{L}$ isolated DNA was used with $23 \mu \mathrm{L}$ of the mix (Buffer GC, enhancer, dNTP (10 mM), 341F, 1046R, enzyme (Taq polymerase) and $\mathrm{dH}_{2} \mathrm{O}$ ). The PCR reaction was performed as follows: 5 min of denaturation at $95{ }^{\circ} \mathrm{C}$ followed by 35 thermal cycles performed for $30 \mathrm{~s}$ at $95{ }^{\circ} \mathrm{C}, 40 \mathrm{~s}$ at $50{ }^{\circ} \mathrm{C}$ and $1 \mathrm{~min}$ at $68^{\circ} \mathrm{C}$, finishing with a final extension step at $68{ }^{\circ} \mathrm{C}$ for $5 \mathrm{~min}$. The PCR product was then incubated at $4{ }^{\circ} \mathrm{C}$ until collected.

The amplification products were analyzed by electrophoresis on a $1.0 \%$ agarose gel stained with ethidium bromide $(3 \mu \mathrm{L} / 100 \mathrm{~mL}$ ). Specific PCR products were cut from the gel under UV-light and isolated from the agarose gel using the Illustra ${ }^{\mathrm{TM}} \mathrm{GFX}^{\mathrm{TM}}$ PCR DNA and Gel Band Purification Kit (GE Healthcare, Eindhoven, The Netherlands), according to the manufacturer's instructions. Adenine (A) was first added to the $3^{\prime}$ end of the GFX product. The PCR products from the biomass were then cloned directly by the TA cloning method by using a TOPO TA cloning kit according to the instructions of the manufacturer (Invitrogen, Life Technologies). Plasmid DNA from single colonies was isolated and 1046R reverse primer was used to amplify the $16 \mathrm{~S}$ rDNA insert before sequencing on 
an ABI 377 DNA sequencer (Applied Biosystems ${ }^{\circledR}$, Life Technologies, Foster City, CA, USA) by using a Big Dye Terminator Cycle Sequencing Ready Reaction Kit (Applied Biosystems ${ }^{\circledR}$ ) [9].

\subsection{Sequencing of $16 S$ rDNA from Pseudomonas Strains}

DNA extraction of putative $P$. aeruginosa strains was performed using the Chelex DNA extraction method: $200 \mu \mathrm{L}$ of $5 \%$ Chelex was placed in four eppendorf tubes along with a loop of colonies. The tubes were vortexed, placed in $55^{\circ} \mathrm{C}$ for $15 \mathrm{~min}$ and vortexed again. The samples were then boiled for $10 \mathrm{~min}$ and placed on ice for $3 \mathrm{~min}$. The samples were then centrifuged (11,000 g) for $7 \mathrm{~min}$. The supernatant was removed and later PCR amplified. PCR amplification and 16S rRNA gene sequencing was then performed as described in sections 2.5 and 2.6 without the cloning process.

\subsection{Phylogenetic Analysis}

Sequences were analysed and edited by using the program Sequencer 4.8 from ABI. Both clones and Pseudomonas isolates sequences were grouped into operational taxonomic units (OTUs) at a threshold of $98 \%$ sequence identity and then aligned by using ClustalW within the MEGA package, version 5.1 [10]. In order to check for the occurrence of cultured species and to confirm Pseudomonas spp. isolates, sequences were searched against those deposited in GenBank, through the NCBI BLAST [11,12]. Neighbor-joining phylogenetic trees were constructed with MEGA 5.1 [10] using a representative sequence from each OTU and related GenBank sequences.

\section{Results}

\subsection{Indicator Bacteria, Total Bacterial Count and Total Cell Count Estimated with Flow Cytometry}

The numbers of colonies that grew on selective media to cultivate E. coli, Enterococcus spp. and P. aeruginosa are summarized in Table 1 . The number of each indicator bacteria refers to bacterial counts in $100 \mathrm{~mL}$ of sample. The flow rate of water into the pools and the pool temperature varied between pools. The flow rate into Lýsuholslaug was about $3.8 \mathrm{~L} / \mathrm{s}$ and the temperature of samples ranged from $32.5{ }^{\circ} \mathrm{C}$ to $33.1{ }^{\circ} \mathrm{C}$. The flow rate into Hveravellir was about $2 \mathrm{~L} / \mathrm{s}$ and the temperature of samples was $33{ }^{\circ} \mathrm{C}$ to $42{ }^{\circ} \mathrm{C}$. The flow rate into Landmannalaugar was about $50 \mathrm{~L} / \mathrm{s}$ and the temperature of samples ranged from $39{ }^{\circ} \mathrm{C}$ to $46{ }^{\circ} \mathrm{C}$. The results for total bacterial counts on R2A agar (cultivated at $50{ }^{\circ} \mathrm{C}, 37^{\circ} \mathrm{C}$ and $22{ }^{\circ} \mathrm{C}$ ) are also summarized in Table 1 . Total bacterial count refers to the number of cfu in $1 \mathrm{~mL}$ of sample. The last three rows present the results of the total cell counts by flow cytometry and are expressed as the number of microbes in $1 \mathrm{~mL}$ of sample. The numbers increased in all pools in relation to time of the day and numbers of bathing guests although some fluctuations during the day were observed. 
Table 1. Numbers of Escherichia coli, Enterococcus spp. and Pseudomonas aeruginosa, sampling time, temperature, $\mathrm{pH}$, guest count, total bacterial counts at cultivation and total cell counts by flow cytometry in samples from each pool.

\begin{tabular}{|c|c|c|c|c|c|c|c|c|c|c|c|c|c|c|c|}
\hline \multirow[b]{2}{*}{ Sample } & \multicolumn{5}{|c|}{ Lýsuhólslaug 17 July 2011} & \multicolumn{5}{|c|}{ Hveravellir 14 August 2011} & \multicolumn{5}{|c|}{ Landmannalaugar 24 August 2011} \\
\hline & 1 & 2 & 3 & 4 & 5 & 1 & 2 & 3 & 4 & 5 & 1 & 2 & 3 & 4 & 5 \\
\hline Time & $13: 10$ & $14: 45$ & $16: 25$ & $18: 30$ & 20:00 & 08:04 & $12: 20$ & $15: 30$ & 18:00 & 20:50 & 09:44 & $12: 25$ & $14: 55$ & $17: 45$ & 20:14 \\
\hline Temp $\left({ }^{\circ} \mathrm{C}\right)$ & 32.5 & 32.7 & 33.1 & 32.9 & 32.6 & 33 & 38 & 36 & 37 & 42 & 36 & 36 & 36 & 38 & 46 \\
\hline $\mathrm{pH}$ & 7 & 7 & 7 & 7 & 7 & 9.5 & 9.5 & 9.5 & 9.5 & 9.5 & 6.5 & 6.6 & 6.7 & 6.6 & 6.7 \\
\hline Guest count $^{1}$ & 0 & 9 & 6 & 6 & 0 & 0 & 9 & 2 & 2 & 3 & 0 & 12 & 18 & 24 & 22 \\
\hline E. coli ${ }^{2,3}$ & 5 & 12 & 7 & 14 & 19 & 220 & 100 & 90 & 150 & 440 & 3 & 5 & 11 & 3 & 4 \\
\hline Enterococcus $^{2,3}$ & 1 & 1 & 3 & 0 & 2 & 47 & 56 & 46 & 81 & 130 & 2 & 1 & 1 & 2 & 3 \\
\hline P. aeruginosa ${ }^{2,3}$ & - & - & - & - & - & 3,000 & 12,000 & 40,000 & 28,000 & 30,000 & 1,400 & 1,800 & 2,300 & 1,300 & 1,900 \\
\hline Grown at $50^{\circ} \mathrm{C}^{4}$ & 2 & 0 & 400 & 1 & 10 & 290 & 1,200 & 2,000 & 2,500 & 1,070 & 830 & 720 & 800 & 770 & 550 \\
\hline Grown at $37^{\circ} \mathrm{C}^{4}$ & 1,500 & 850 & 800 & 1,500 & 1,070 & 380 & 1,550 & 1,400 & 1,500 & 1,650 & 1,200 & 910 & 680 & 780 & 700 \\
\hline Grown at $22{ }^{\circ} \mathrm{C}^{4}$ & 2,100 & 1,500 & 2,000 & 2,400 & 535 & 135 & 90 & 155 & 150 & 205 & 790 & 780 & 680 & 630 & 740 \\
\hline Bacteria $^{5}$ & $2.6 \times 10^{6}$ & $1.9 \times 10^{6}$ & $7.5 \times 10^{5}$ & $5.4 \times 10^{5}$ & $4.9 \times 10^{5}$ & $1.6 \times 10^{5}$ & $1.2 \times 10^{5}$ & $2.7 \times 10^{5}$ & $1.7 \times 10^{5}$ & $3.2 \times 10^{5}$ & $1.1 \times 10^{5}$ & $1.2 \times 10^{5}$ & $1.4 \times 10^{5}$ & $1.1 \times 10^{5}$ & $1.3 \times 10^{5}$ \\
\hline Algae/Larger particles ${ }^{5}$ & $1.5 \times 10^{6}$ & $2.0 \times 10^{6}$ & $9.2 \times 10^{5}$ & $9.2 \times 10^{5}$ & $8.7 \times 10^{5}$ & $8.7 \times 10^{4}$ & $5.5 \times 10^{4}$ & $4.0 \times 10^{5}$ & $2.3 \times 10^{5}$ & $1.3 \times 10^{5}$ & $2.9 \times 10^{4}$ & $5.4 \times 10^{4}$ & $6.4 \times 10^{4}$ & $3.3 \times 10^{4}$ & $3.2 \times 10^{4}$ \\
\hline Total cell count ${ }^{5}$ & $5.3 \times 10^{6}$ & $5.7 \times 10^{6}$ & $2.8 \times 10^{6}$ & $2.8 \times 10^{6}$ & $2.8 \times 10^{6}$ & $4.2 \times 10^{5}$ & $3.2 \times 10^{5}$ & $8.9 \times 10^{5}$ & $5.8 \times 10^{5}$ & $6.4 \times 10^{5}$ & $2.3 \times 10^{5}$ & $2.6 \times 10^{5}$ & $3.0 \times 10^{5}$ & $2.4 \times 10^{5}$ & $2.5 \times 10^{5}$ \\
\hline
\end{tabular}

${ }^{1}$ In the pool during sampling. Total guest count on sampling day: Lýsuhólslaug: 79, Hveravellir: approx. 100 and Landmannalaugar: approx. $200 .{ }^{2}$ Plate counts (cfu/100 mL).

${ }^{3}$ E. coli and Enterococcus confirmed as described earlier, P. aeruginosa unconfirmed. ${ }^{4}$ Total bacterial plate counts on R2A medium (cfu/mL). ${ }^{5}$ FACS cell count/mL.

${ }^{(-)}$Not measured in this pool. 
Figure 2. (a) Phylogenetic tree based on neighbor-joining analysis of the 16S rRNA gene sequences of 32 bacterial clones from Lýsuhólslaug; (b) 29 bacterial clones from Hveravellir; (c) 32 bacterial clones from Landmannalaugar. Aquifex bacteria were used as an outgroup in all the trees. The scale bar represents the expected $\%$ of substitutions per nucleotide position. All OTUs from samples are marked in bold for each clone and their numbers if more than one. The GenBank accession numbers of reference sequences are given for each OTU.

(a)

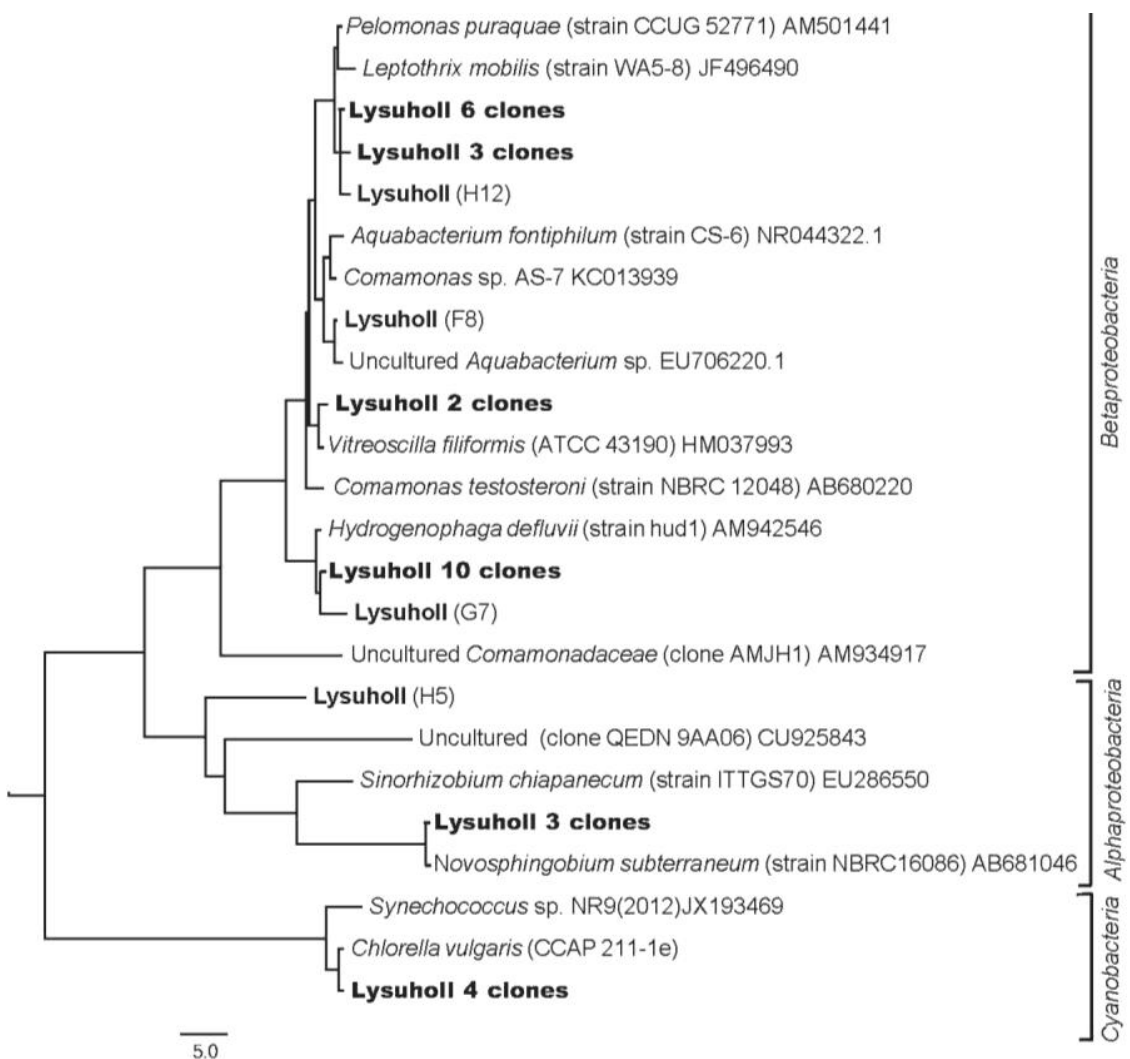

(b)

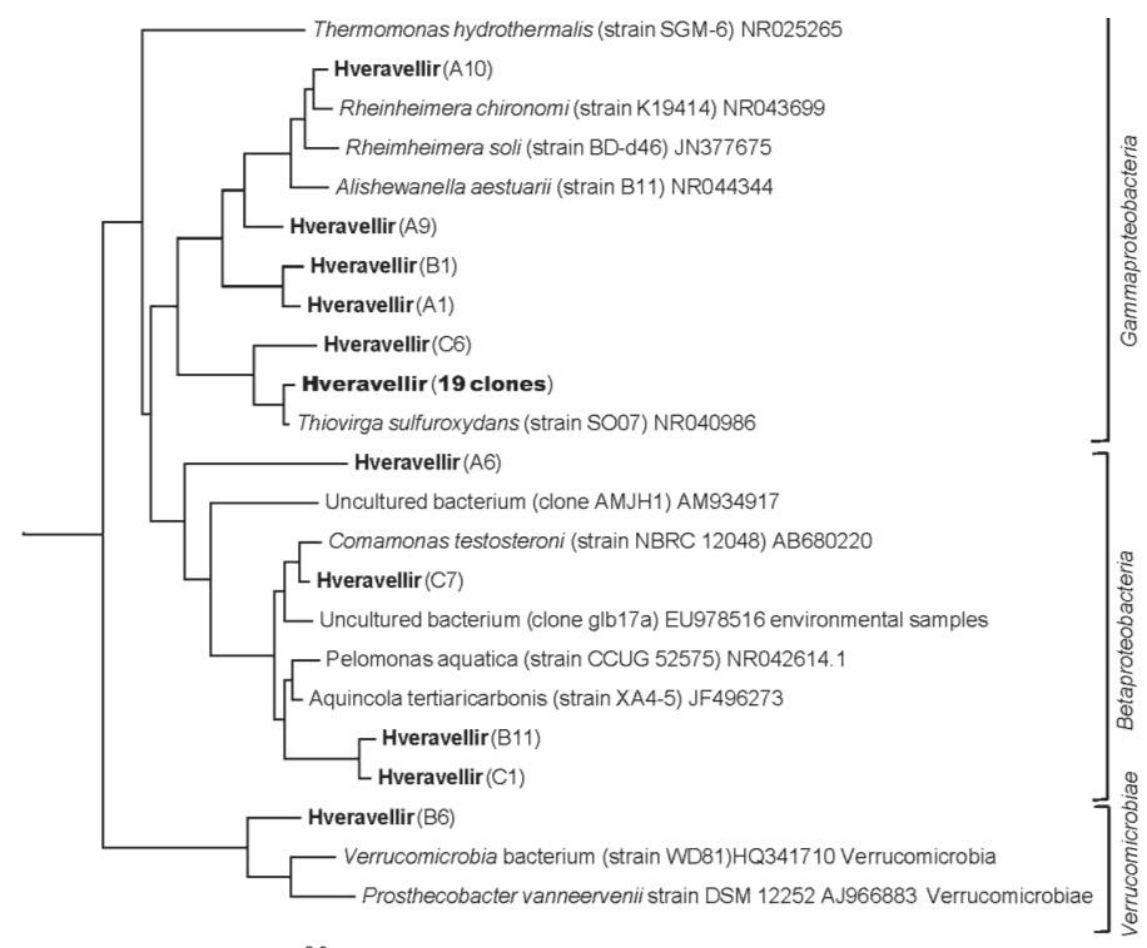


Figure 2. Cont.

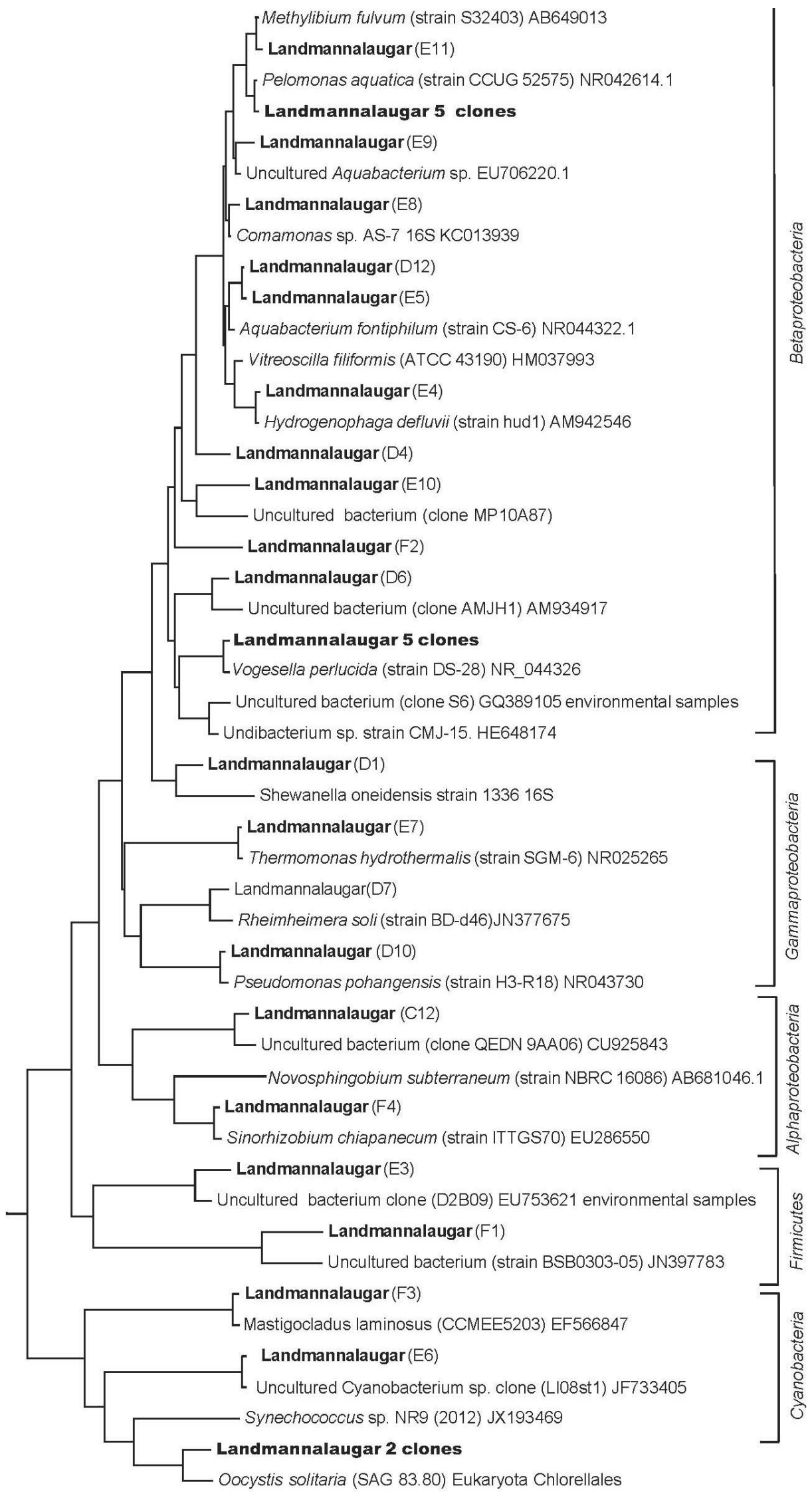




\subsection{S rRNA Gene Sequencing}

In total, 16S rRNA genes from 93 clones were sequenced and about 500-630 base pairs (bp) of each clone was used for phylogenic analysis after omitting unreadable bp in sequences. The majority of the clones or OTUs could be affiliated to Proteobacteria (alpha, beta and gamma subgroups) and about 25\% (22 OTUs) showed less than 97\% similarity with any known type strain, thereof 3 clones that could not be affiliated into specific genera. Figures 2(a), (b) and (c) show neighbour-joining trees of sequences from the $16 \mathrm{~S}$ rRNA clone libraries of each pool. The scale bar represents the expected $\%$ of substitutions per nucleotide position and Aquifex bacteria were used as an outgroup. The clusters of clones in each tree represent clones with $>99 \%$ sequence similarity. GenBank accession numbers are given for each reference strain or OTU.

The phylogenetic tree for Lýsuhólslaug (Figure 2 (a)) shows that the most abundant groups are similar to Pelomonas puraquae and Leptothrix mobilis species (nine clones), Hydrogenophaga defluvii (10 clones), Novosphingobium subterraneum (three clones) and some chloroplasts Chlorella vulgaris (four clones). One clone could not be affiliated to any genus.

The phylogenetic tree for Hveravellir (Figure 2 (b)) shows that the most abundant group showed high similarity to the species Thiovirga sulfuroxydans (19 clones). Most of the other clones could not be affiliated to any known genus, except for Comamonas and Rheinheimera.

The phylogenetic tree for Landmannalaugar (Figure 2 (c)) shows very high diversity of OTUs in the samples analysed. The OTUs belong to five phyla (beta-, gamma- and alphaproteobacteria, Firmicutes and Cyanobacteria) and most of them could be affiliated with high similarity to known genera. About six OTUs could not be affiliated to known genus, but four of them to uncultured environmental clones.

Figure 3. Phylogenetic tree based on neighbor-joining analysis of the $16 \mathrm{~S}$ rRNA gene sequences of 4 putative Pseudomonas strains. The 16S rRNA sequence of Aquifex was used as an outgroup. The scale bar represents the expected \% of substitutions per nucleotide position.

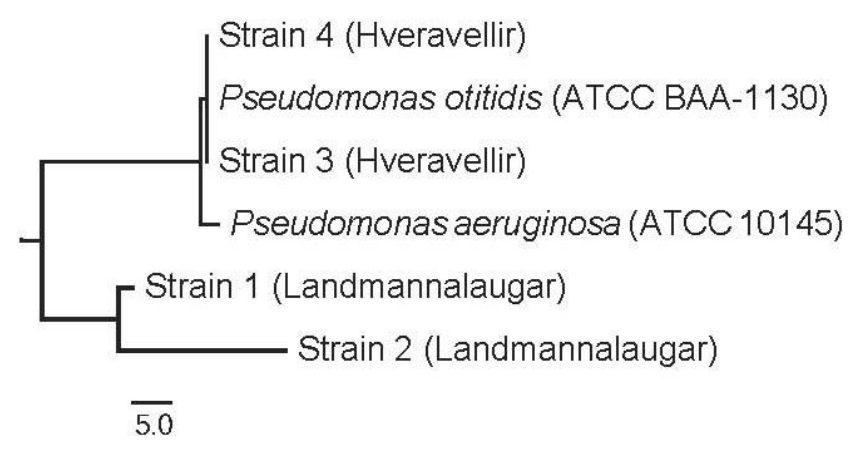

\section{Pseudomonas Strains}

The confirmation of putative Pseudomonas aeruginosa strains by Nessler's reagent was not definitive. Therefore, the $16 \mathrm{~S}$ rRNA genes from the positive cultured isolates were sequenced for further inspection and to confirm that the strains belonged to the Pseudomonas genus and to what extent to $P$. aeruginosa. Isolates 1 and 2 were isolated from Landmannalaugar and isolates 3 and 4 
from Hveravellir. The isolates came from samples 4 and 5 in both locations. The phylogenetic tree (Figure 3) shows that isolates 3 and 4 have 100\% similarity to P. otitidis and 99\% similarity to $P$. aeruginosa. Isolates 1 and 2 are more distantly related.

\subsection{Norovirus Detection in Samples}

Norovirus was not detected with the method used in this study in any of the samples collected from the three natural pools.

\section{Discussion}

The study revealed that the three pools meet the microbiological requirements of the Directive no. 2006/7/EC on quality of bathing water in inland areas and had an excellent water quality with respect to E. coli $(<500 \mathrm{cfu} / 100 \mathrm{~mL})$ and Enterococcus ( $<200 \mathrm{cfu} / 100 \mathrm{~mL})$ criteria. However, these limits are quite high and it is of concern whether they should be transferred to the Icelandic natural thermal pools. The physiological conditions of most natural pools are very good for bacterial proliferation and excessive inoculation of pathogens into the pools from humans could cause health problems. According to the guideline given in the Icelandic regulations for the prevention of water pollution no. 796/1999 for recreational waters, both Lýsuhólslaug and Landmannalaugar meet the requirements "I" in the regulation, which means they have little or no fecal contamination. The pool at Hveravellir exceeds requirements "III and IV" in the regulation which indicates some to high fecal contamination. Outside of Europe the limits are lower, e.g., the U.S. Environmental Protection Agency has since 1986 set the limit to $126 \mathrm{cfu} / 100 \mathrm{~mL}$ for E. coli and $33 \mathrm{cfu} / 100 \mathrm{~mL}$ for Enterococcus [13]. Our study is in agreement to the study performed in 2002, where the public seems to affect the quality of the water, but not enough to become harmful to others pool guests [2]. The unequal numbers of bacteria in the pools is most likely due to different total volume of the pools, water flow, the number of pool guests and the cleaning of the pools. However, it can be asserted that the tourist burden on the pool at Hveravellir had reached its maximum capacity on the day sampling took place. Interestingly but not surprisingly, the numbers of bacteria that grew at $55^{\circ} \mathrm{C}$ were higher or at least 9 to 17 times in average higher in the more natural pools at Landmannalaugar and Hveravellir, respectively, than at Lýsuhólslaug. These results go into the opposite direction for the bacteria that grew at $22{ }^{\circ} \mathrm{C}$ as the numbers of bacteria in Lýsuhólslaug were 2 to 11 higher than in average higher than at Landmannalaugar and Hveravellir, respectively. This difference may be explained by the lower temperature measured at Lýsuholslaug, stimulating the growth of bacteria tolerating better lower temperatures compared to the other pools and vice versa. The number of bacteria that grew at $37{ }^{\circ} \mathrm{C}$ was similar in all pools. The flow cytometry technique identified more cells than were measured by the cultivation methods employed in the present study. This suggests that nonculturable bacteria were present in the sample, or in a nonculturable state. That correlates with the theory that only $<1-5 \%$ of microorganisms can be grown by conventional methods [9]. It should be noted that the total bacterial counts in this study should not be taken as absolute values as only one count represents each sampling point. Therefore we observe here an increasing trend for the number of cells with time and bath guest but its statistical significance is not demonstrated. The guests count on sampling days were accurate for Lýsuhólslaug (79), but estimated in Hveravellir (100) and Landmannalaugar (200). 
In this study, DNA was isolated from all microorganisms (whether they were alive or not) in the samples. This will include bacteria that were not cultured on the media used, either due to their unculturable state or unsatisfied growth requirements. Sequencing of 16S rRNA genes from the last sample collected from each pool (32 clones) was performed. A total of 93 clones were successfully sequenced and about 500-700 bases of each gene were retrieved. These sequences or OTUs showed homology to alpha-, beta- and gammaproteobacteria, Cyanobacteria, and interestingly also from eukaryotic cells. This suggests that free floating chloroplasts that contain 16S rRNA genes were released from eukaryotic algal cells but these cells were also detected in high numbers with flow cytometry. Most of the OTUs could be affiliated to bacterial species that have been isolated or detected before, in hot springs or pools, and some in water and soil. No pathogens were detected by this method. Interestingly, many of the OTUs detected in the samples were not closely related to bacteria that have been cultivated. The OTUs' profiles obtained differed among the three pools but three genera were found in more than one pool: Pelomonas, Hydrogenophaga and Rheinheimera. Overall, the range of biodiversity in the pools was very different, which could be explained by the environmental conditions; $\mathrm{pH}$, conductivity and concentrations of chemicals (e.g., silica) are different for each pool [14-16].

All samples contained bacterial strains that were grown on the culture medium specific for P. aeruginosa. Many colonies were fluorescent, but confirmation with formation of ammonia from cultures of acetamide broth was not conclusive. The change of color should be from a light yellowish color to bright yellow or red-brown color, but the changes showed a paler yellow color than the unambiguous confirmation of $P$. aeruginosa should show. Therefore, four putative Pseudomonas isolates were selected for sequencing of 16S rRNA genes to confirm our color test. The results showed that strains from Hveravellir had $100 \%$ gene similarity to $P$. otitidis, which can cause ear infection (otitis) and was first described in 2006 [17]. These strains also had a 99\% gene similarity to $P$. aeruginosa, and BLAST searches revealed that strains also had a $99 \%$ gene similarity to P. alcaligenes, P. mosselii and P. guezennei. The Pseudomonas strains from Landmannalaugar were more distantly related to these species. All these Pseudomonas species, except for P. guezennei, are opportunistic pathogens, but it is not known whether the strains in this study have virulence factors. Nevertheless, according to Icelandic regulation (No. 814/2010), operators of swimming pools must screen for $P$. aeruginosa, and there is zero tolerance for such bacteria in bathwater.

The OTUs that were 99-100\% homogenous to Hydrogenophaga and Thiovirga spp. were the most abundant in the samples from Lýsuhólslaug and Hveravellir. The diversity was especially low in Hveravellir as one taxon was dominating the sample with Thiovirga spp. It would be necessary to sequence more clones or to perform deep sequencing to detect underrepresented or rare microorganisms [7]. No pathogens were detected by sequencing in this study, but the screening of E. coli, Enterococcus spp. and Pseudomonas spp. by selective culture media revealed that their number can become quite large when the guest count in the natural pools is high and water flow is too low to renew the water sufficiently.

The water in Landmannalaugar flows at a high rate $(50-75 \mathrm{~L} / \mathrm{s})$ and the renewal rate of the water is fast compared to the size of the pool (about $42 \mathrm{~min}$ ). It can therefore be assumed that bacterial contamination is low in spite of numerous visitors. Interestingly, the pool contained similar numbers of bacteria that grew at $50{ }^{\circ} \mathrm{C}, 37^{\circ} \mathrm{C}$ and $22{ }^{\circ} \mathrm{C}$, despite its rather high water temperature. At Hveravellir the flow is low (about 1-3.5 L/s, that comes in spurts) and a large number of visitors generates a lot of 
stress on the pool environment. The pool capacity is about 2.1 tonnes of water and the renewal time is about $6 \mathrm{~h}$. The number of E. coli, Enterococcus spp. and Pseudomonas spp. was highest in this pool. Moreover the pool contained the highest number of bacteria that grew at $50{ }^{\circ} \mathrm{C}$ and $37{ }^{\circ} \mathrm{C}$ but the lowest at $22{ }^{\circ} \mathrm{C}$, which may be related to the high water temperature. The flow is also quite low (3.8 L/s) in Lýsuhólslaug, and it takes about $5 \mathrm{~h}$ to renew the water in that pool. However, all visitors must shower first before entering the pool, which decreases the spike from human bacterial flora into the pool. It therefore has a good effect on the microbiological quality of the water as we have observed in this study. Nevertheless the pool contained the highest number of bacteria that grew at $37{ }^{\circ} \mathrm{C}$ and $22{ }^{\circ} \mathrm{C}$, but lowest at $50{ }^{\circ} \mathrm{C}$ as could be expected from the lower water temperature.

Our findings suggest that the quality of bathing water depends on the interaction of guest count, pool size, flow rate and the hygiene of pool guests. The hygiene part is important because guests carry dirt on their skin and swimwear to the water (e.g., residues from urine and feces, skin particles, etc.). It is therefore important that bathers wash thoroughly before entering the pools. It is also very important that people stay away from the pools after illnesses (e.g., diarrhea). Very young children, elderly and people with impaired immune systems should avoid natural pools because of the fecal contamination that may be present in the pool and $P$. otitidis that can cause ear infection. It cannot be ruled out that $P$. aeruginosa is present in natural pools, which can cause a variety of other infections such as pneumonia, septic shock, ear, urinary tract, gastrointestinal and skin infections [18].

Health authorities report very few infections associated with natural pools. This could be a fact, so there are no problems associated to natural pools, or the problem could be hidden. The bathers might not link their illness to their visit to a natural pool or seek medical help due to symptoms. If tourists in Iceland get an infection (e.g., skin, respiratory, gastrointestinal or urinary tract) during their travel around the country, it can become difficult to trace its source. This is particularly the case for foreign tourists staying in the country for a few days, doing various outdoor activities, and tasting various kinds of food. The infection might not even be detected until they get home.

The indicator bacteria E. coli and Enterococcus indicate that fecal contamination is present, and thus potential contamination by other intestinal bacteria. The pools at Hveravellir and Landmannalaugar are probably the most visited natural thermal pools in Iceland (including the Blue Lagoon and the beach at Nauthólsvík), so there is reason to believe that microbial contamination will not become greater in other pools in the country.

Our results indicate that it is unlikely that humans are at risk for norovirus infection in the natural pools, although individual cases might occur, as in many conventional swimming pools abroad. However, our sampling was only performed once in each pool, which is not enough for any speculation on the possible presence of noroviruses, and more thorough studies will be needed.

\section{Acknowledgments}

The authors would like to thank Alexandra M. Klonowski, Eyjólfur Reynisson, Sveinn H. Magnússon and Sólveig Ólafsdóttir for guidelines and assistance. We would also like to thank Hjalti J. Guðmundsson, Brynja Jóhannsdóttir and Ólafur A. Jónsson at The Environmental Agency of Iceland for discussions and information. Finally, the authors thank Hélène L. Lauzon for critical reading and the anonymous reviewers for their contribution. 


\section{Conflict of Interest}

The authors declare no conflict of interest.

\section{References}

1. Hróarsson, B.; Jónsson, S.S. Hot Springs in Iceland; Mál og menning: Reykjavík, Iceland, 1991, in Icelandic.

2. Environmental Agency of Iceland. A Research on Bacterial Levels in Icelandic Geothermal Pools; Umhverfisstofnun: Reykjavík, Iceland, 2003, in Icelandic.

3. Martins, M.T.; Sato, M.I.Z.; Alves, M.N.; Stoppe, N.C.; Prado, V.M.; Sanchez, P.S. Assessment of microbiological quality for swimming pools in South America. Water Res. 1995, 29, 2417-2420.

4. Niewolak, S.; Opieka, A. Potentially pathogenic microorganisms in water and bottom sediments in the Czarna Hańcza river. Pol. J. Environ. Stud. 2000, 9, 183-194.

5. Umhverfisstofnun. Monitoring Project on Quality and Safety in Swimming Pools in the Summer of 2008; Umhverfisstofnun: Reykjavík, Iceland, 2009, in Icelandic.

6. Schets, F.M.; Schijven, J.F.; de Roda Husman, A.M. Exposure assessment for swimmers in bathing waters and swimming pools. Water Res. 2011, 7, 2392-2400.

7. Marteinsson, V.Th.; Rúnarsson, Á.; Stefánsson, A.; Thorsteinsson, Th.; Jóhannesson, T.; Magnússon, S.; Reynisson, E.; Einarsson, B.; Wade, N.; Morrison, H.G.; Gaidos, E. A pervasive microbial community in waters under the Vatnajökull ice cap, Iceland. ISME J. 2012, 7, 427-437.

8. Huber, J.A.; Welch, D.B.M.; Morrison, H.G.; Huse, S.M.; Neal, P.R.; Butterfield, D.A.; Sogin, M.L. Microbial population structures in the deep marine biosphere. Science 2007, 318, 97-100.

9. Marteinsson, V.Th.; Hauksdóttir, S.; Hobel, C.V.; Kristmannsdóttir, H.; Hreggvidsson, G.Ó.; Kristjánsson, J.K. Phylogenetic diversity analysis of subterranean hot springs in Iceland. Appl. Environ. Microbiol. 2001, 9, 4242-4248.

10. Tamura, K.; Peterson, D.; Peterson, N.; Stecher, G.; Nei, M.; Kumar, S. MEGA5: Molecular evolutionary genetics analysis using maximum likelihood, evolutionary distance, and maximum parsimony methods. Mol. Biol. Evol. 2011, 28, 2731-2739.

11. Altschul, S.F.; Gish, W.; Miller, W.; Myers, E.W.; Lipman, D.J. Basic local alignment search tool. J. Mol. Biol. 1990, 215, 403-410.

12. BLAST: Basic Local Alignment Search Tool. Available online: http://blast.ncbi.nlm.nih.gov (accessed on 25 October 2011).

13. U.S. Environmental Protection Agency. EPA Action Plan for Beaches and Recreational Waters, Reducing Exposures to Waterborne Pathogens; Office of Research and Development and Office of Water U.S. Environmental Protection Agency: Washington, DC, USA, 1999.

14. Hjartarson, Á.; Ólafsson, M. Hveravellir-Mapping of the Geothermal Area; Ísor: Reykjavík, Iceland, 2005, in Icelandic.

15. Bjarnason, J.Ö.; Ólafsson, M. In Torfajökull-Chemicals in Geothermal Steam and Water; Orkustofnun: Reykjavík, Iceland, 2000, in Icelandic.

16. Karlsdóttir, R.; Jóhannesson, H.; Benjamínsson, J. A Research on Geothermal Heat at Lýsuhóll in Staðarsveit, Snafellsnes; Orkustofnun: Reykjavík, Iceland, 1981, in Icelandic. 
17. Clark, L.L.; Dajcs, J.J.; McLean, C.H.; Bartell, J.G.; Stroman, D.W. Pseudomonas otitidis sp. nov., isolated from patients with otic infections. Int. J. Syst. Evol. Microbiol. 2006, 56, 709-714.

18. Balcht, A.L.; Smith, R.P. Pseudomonas aeruginosa: Infections and Treatment (Infectious Disease and Therapy); Marcel Dekker: New York, USA, 1994; Volume 12.

(C) 2013 by the authors; licensee MDPI, Basel, Switzerland. This article is an open access article distributed under the terms and conditions of the Creative Commons Attribution license (http://creativecommons.org/licenses/by/3.0/). 